\title{
SUITTES GRANITICAS DO BATÓLITO PELOTAS NO RIO GRANDE DO SUL: PETROGRAFIA, TECTÔNICA E ASPECTOS PETROGENÉTICOS
}

\author{
RUY PAULO PHILIPP ${ }^{1}$ E RÔMULO MACHADO ${ }^{2}$
}

\begin{abstract}
SUÍTES GRANÍTICAS DO BATÓLITO PELOTAS NO RIO GRANDE DO SUL: PETROGRAFIA, TECTÔNICA E ASPECTOS PETROGENÉTICOS The Pelotas Batholith, situated in the castern part of the Sul-Rio-Grandense shield, is $400 \mathrm{~km}$-long and 80-120 kmwide. It is mostly constituted by six intrusive suites: Pinheiro Machado Intrusive Suite, Viamão Intrusive Suite, Encruzilhada do Sul Intrusive Suite, Cordilheira Granitic Suite and the Dom Feliciano Granitic Suitc. This association is composed of high-K calc-alkaline rocks, with minor amounts of alkaline granitoids. Alkaline and peralkaline terms are represented by the Bela Vista Granite and rhyolite dikes. The successive emplacement of granitic rock associations is largely related to the activity of extensive, ductile to brittle-ductile shear zones. The suites within the batholith have been affected by three successive deformational events, from which the first two are ductile $\left(D_{1}\right.$ and $\left.D_{2}\right)$ and one is ductilebrittle to brittle $\left(D_{3}\right)$. Granitoids from the Pinheiro Machado Intrusive Suite record the oldest deformation event $\left(D_{1}\right)$, which is characterized by flat-lying shear zones with oblique stretching lineations indicating top-to-ESE movement. The structural evolution determined for this region is compatible with a transpressive tectonic model related to oblique plate convergence.
\end{abstract}

Keyowords: Pelotas batholith, Petrography, Tectonic, Petrogenesis

RESUMO O Batólito Pelotas, situado na porção leste do Escudo Sul-Rio-Grandense, possui somente no Rio Grande do Sul extensão de cerca de $400 \mathrm{~km}$ e largura entre 70 e $110 \mathrm{~km}$. É composto por seis suítes graniticas: Suíte Intrusiva Pinheiro Machado (SIPM), Suíte Intrusiva Erval (SIE), Suíte Intrusiva Viamão (SIV), Suíte Intrusiva Encruzilhada do Sul (SIES), Suíte Granítica Cordilheira (SGC) e Suítc Granítica Dom Feliciano (SGDF) (Philipp 1998). A SIPM possui composição expandida (diorítica/tonalítica/granodiorítica/monzogranítica), a SIE, monzogranítica equigranular; a SIV, monzogranítica porfirítica com granodioritos e sienogranitos subordinados; a SIES, monzogranítica a álcalifeldspato granítica, com textura porfirítica e equigranular grossa: a SGIDF, sienogranítica, sendo associada a greisens e mineralizações de $\mathrm{Sn}$. A SGC. de composição sienogranítica a granodiorítica. com textura equigranular. é caracterizada por leucogranitos com moscovita, contendo turmalina e granada como acessórios. São comuns associações básicas a intermediárias com relações de mistura de magmas. A SIPM é cálcioalcalina de médio a alto-K, com idade entre 620 a $605 \mathrm{Ma}$; as demais suítes são cílcio-alcalina de alto-K, com idades entre 595 e $550 \mathrm{Ma}$, com a SGC sendo peraluminosa. Manifestações alcalinas e peralcalinas são representadas por diques riolíticos e pelo Granito Bela Vista, ambos pertencentes a SGDF. São identificados três eventos deformacionais: dois mais antigos $\left(D_{1}\right.$ e $\left.D_{2}\right)$, de natureza dúctil, e um mais novo (D3), rúptil. A colocação desta suítes ocorreu em regime transpressivo, durante um evento de convergência oblíqua de placas.

Palavras-Chaves: Batólito Pelotas, Petrografia, Tectônica, Petrogênese

INTRODUÇÃO O Batólito Pelotas, situado na porção leste do Escudo Sul-rio-grandense, apresenta no Rio Grande do Sul extensão aproximada de $370 \mathrm{~km}$ c largura entre 70 a $110 \mathrm{~km}$. Sua continuidade para norte, em Santa Catarina e, para sul, no Uruguai, é sugerida por levantamentos geológicos e geofísicos (Shukowsky et al. 1991; Hallinan et al. 1993) (Fig.1). O batólito foi definido originalmente como um complexo plutônico, multi-intrusivo e polifásico, resultante de uma longa evolução, conseqüente da adição de distintos processos tectônicos (Fragoso Cesar et al. 1986). No presente trabalho, como em Philipp (1998), são reconhecidas seis suítes graníticas, incluindo também rochas básicas e septos das encaixantes. A reconstituição estratigrálica e tectônica do batólito é o resultado da integração das informações cartográlicas, estruturais, geoquímicas e geocronológicas disponíveis, bem como de dados adicionais gerados neste trabalho. Como resultado, foi possível separar as Suítes Intrusivas Pinheiro Machado (SIPM), Erval (SIE), Viamão (SIV) e Encruzilhada do Sul (SIES), e as Suítes Graníticas Cordilheira (SGC) e Dom Feliciano (SGDF) (Fig. 2). Além disso, associadas a SIV e SGDF, foram identificadas rochas básicas de posicionamento indefinido, como Gabros Passo da Fabiana (Fragoso Cesar 1991) e Diorito Capim Branco (Wildner et al. 1994). Incluem-se também exposições vulcânicas e subvulcânicas ácidas, constituindo enxames de diques ou pequenos platôs de rochas piroclásticas, como os Diques Riolíticos Asperezas e Tufos e Ignimbritos Ana Dias (Fragoso Cesar et al. 1986). O Granito Bela Vista (Philipp et al. 1991) é a única ocorrência conhecida de magmatismo peralcalino no Batólito Pelotas. Estudos isotópicos (Cordani et al. 1974, Soliani Jr. 1986, May 1990, Chemale Jr. et al. 1995. Babinski et al. 1997, Silva et al. 1997 e 1999) apontam para uma evolução brasiliana (620-550 Ma) na constituição do batólito, sugerindo intensa participação de processos de refusão crustal, com adição subordinada de material juvenil. O modelo tectônico concebido para o Batólito Pelotas envolve um evento inicial de subducção sob uma margem continental ativa espessada, seguindo-se um evento colisional com magmatismo de crosta continental duplicada, que passa para um magmatismo relacionado ao período final de relaxamento $\mathrm{c}$ soerguimento pós-colisional. A presença de limites tectônicos reforça o caráter alóctone do Batólito Pelotas no contexto do Cinturão Dom Feliciano (Fragoso Cesar et al. 1986), sendo este aspecto compatível com a delinição deste segmento como um terreno exótico e suspeito (Terreno Piratini, Fragoso Cesar 1993; Terreno Pelotas, Fragoso Cesar et al. 1998).

TRABALHOS ANTERIORES Os primeiros trabalhos do leste do Escudo Sul-rio-grandense descrevem rochas cristalinas pré-cambrianas e interpretam esta porção do escudo como uma área estável denominada "Cráton Dom Feliciano" (Carvalho 1932, Leinz et al. 1945, Goñi $e$ i al. 1962, Picada 1965, Tessari \& Picada 1966, Tessari \& Gilfoni 1970). Posteriormente, esta região foi considerada como um antigo embasamento Pré-Cambriano retrabalhado durante o Ciclo Brasiliano, com sua porção oriental sendo englobada no Maciço Mediano de Pelotas ( Hasui et al. 1975, Almeida et al. 1981). Seguem os trabalhos que utilizam o conceito da Tectônica de Placas e consideram a região como um cinturão orogênico brasiliano (Ribciro \& Fantincl 1978, Fragoso Cesar 1980, 1991, Jost \& Hartmann 1984, Soliani Jr. 1986, Fragoso Cesar et al. 1986, Figuciredo et al. 1990, Philipp 1991, Fernandes el al. 1992a)

Os mapeamentos regionais realizados por Tessari \& Picada (1966), Tessari \& Giffoni (1970), Ribeiro (1977) e Frantz \& Remus (1986) cnfatizam o caráter essencialmente magmático desta região do escudo, assinalando a presença de um embasamento de rochas metamórficas (para e ortoderivadas), com registro de uma história geológica complexa, incluindo eventos de metamorfismo e deformação.

Após a definição do Batólito Pelotas como entidade plutônica por Fragoso Cesar et al. (1986), ocorreram avanços significativos de caracterização geoquímica, geocronológica e tectônica do batólito, com a sua evolução magmática do batólito passando então a ser considerada

I - Centro de Estudos de Petrologia e Geoquímica (CPGq), Instituto de Geociências, UFRGS. Av. Bento Gonçalves, 9500, CEP 91540- 000, Porto Alegre - RS, CP-15001, e-mail: ruy.philipp @ufrgs.br

2 - Instituto de Geociências da USP e Pesquisador do CNPq, Rua do Lago, 562 . Cidade Universitária, 05422-970, São Paulo-SP, e-mail: rmachado@usp.br 


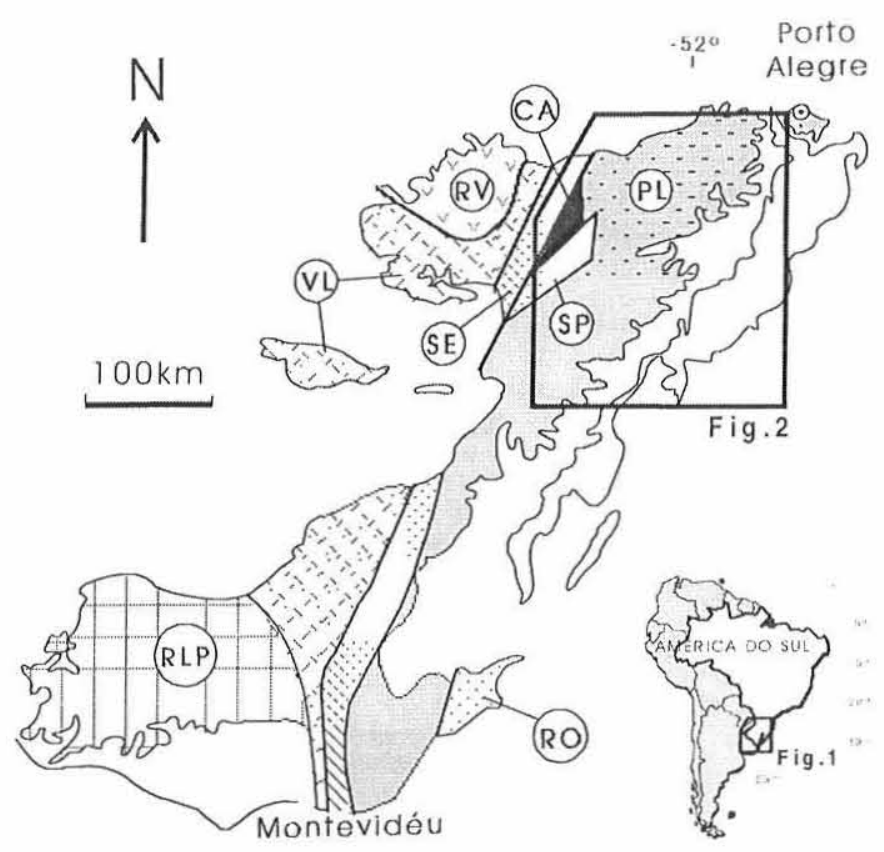

E. A Rio Valentines (VL)

Cerro da Árvore (CA)

Rio Vacacai (RV)

Pelotas (PL)

Rio de La Plata (RLP)

Rocha (RO)

Serra das Encantadas (SE)

Serra dos Pereiras (SP)

Lavalleja (LA)

Figura 1. Localizaşão do Batólito Pelotas no contexto geotectônico do sul do Brasil e Uruguai (extraido de Fragoso Cesar et al. 1998).

definitivamente como relacionada ao Ciclo Brasiliano (Frantz \& Remus 1986, Soliani Jr. 1986, Figueiredo et al. 1990, Philipp 1990). Coube a Figueiredo et al. (1990) o primeiro trabalho de geoquímica sobre o batólito, seguindo-se outros trabalhos, gerais ou específicos, com o mesmo tipo de abordagem, incorporando também dados estruturais, sobretudo das regiões de Pelotas, Canguçu, Pinheiro Machado e Piratini (Philipp 1990, Gomes 1990, Mesquita 1991, Fernandes et al. 1992a,b, Frantz \& Nardi 1992a, Philipp et al. 1991, 1993).

Os primeiros trabalhos de geocronologia realizados sobre o batólito remontam ao início da década de 70. Inicialmente foram gerados dados isotópicos $\mathrm{K}-\mathrm{Ar}$ e $\mathrm{Rb}-\mathrm{Sr}$, que se acham incorporados em artigos de sínteses regionais (Cordani et al. 1974). Destacam-se nesta linha os estudos de Soliani Jr. (1986), que apresenta idades Rb-Sr de 830-800 Ma, para gnaisses e migmatitos, de 780-770 Ma, para granitóides foliados, e 550-450 Ma, para granitos isótropos. Segue-se o trabalho de May (1990), onde são apresentados os primeiros resultados isotópicos $\mathrm{Sm}-\mathrm{Nd}$, juntamente com idades $\mathrm{Rb}-\mathrm{Sr}$ de granitóides da porção central do batólito e de rochas metamórficas da sua porção oriental. As primeiras idades U-Pb (em zircão) e Sm-Nd se devem aos trabalhos de Chemale Jr. et al. (1995), Babinski et al. (1997) e Silva et al. (1997, 1999).

O acervo geocronológico disponível para o Batólito Pelotas sugere um intervalo de tempo relativamente curto para a geração do magmatismo granítico, com início ao redor de 630 a 620 Ma, e término por volta de $550 \mathrm{Ma}$. Datações $\mathrm{Ar}$-Ar efetuadas em micas de milonitos de zonas de cisalhamento da região de Canguçu e Pinheiro Machado indicam idades de 534 e $536 \mathrm{Ma}$. Este valores foram interpretados como a idade da última movimentação destas estruturas na porção leste do batólito (Philipp 1998).
ARCABOUÇO DO BATÓLITO Limites Geológicos Os contatos do Batólito Pelotas são definidos por zonas de cisalhamento de alto ângulo, com movimentação dominantemente sinistral. Estas zonas são caracterizadas por espessas faixas de rochas miloníticas de direção NE-SW. O limite oeste do batólito é com as Zonas de Cisalhamento Dorsal do Canguçu (Mesquita \& Fernandes 1990) e Passo do Marinheiro (Picada 1971). O seu limite leste aflora apenas no Uruguai, onde está em contato com o Grupo Rocha através da Zona de Cisalhamento Alferes-Cordilheira (Masquelin 1989). O limite norte é com os sedimentos da Bacia do Paraná, e o leste é com os sedimentos da Planícic Costeira. Estas zonas de cisalhamento de alto ângulo foram responsáveis tanto pela geometria alongada do batólito na direção NESW, como pelo controle na colocação e na deformação interna de suas unidades graníticas, respondendo pela geração de foliações magmáticas $\mathrm{c}$ no estado sólido. As encaixantes a oeste do batólito são os Gnaisses Encantadas, o Complexo Cerro da Árvore (Jost 1981) e a Suítc Metamórfica Porongos (Marques et al. 1998). A primeira, em grau metamórfico alto, a segunda, em fácies xisto verde médio a anfibolito c, a última, em fácies xisto verde.

Evidências Geofísicas Coube a Shukowsky et al. (1991), com base em dados gravimétricos, a primeira tentativa de caracterização regional das discontinuidades pré-cambrianas no sul do Brasil e oeste do Uruguai. Uma reavaliação destes dados, incluindo modelagem e informações magnetométricas (Hallinan et al. 1993), permitiu uma subdivisão do Escudo Sul-rio-grandense em vários blocos crustais, onde se destacam anomalias contínuas NNE, interpretadas como reflexos da tectônica brasiliana. No domínio dos Gnaisses Encantadas aparece uma anomalia positiva, que contrasta com uma anomalia negativa junto ao limite oeste do batólito. Um padrão gravimétrico com anomalia negativa E-W, situado a sudoeste da Lagoa Mirim, foi atribuido a intrusões profundas e lavas básicas mesozóicas (Costa \& Ramgrab 1989). Padrões magnéticos na região de Pinheiro Machado (Costa et al. 1994a) são relacionados às zonas de cisalhamento dúcteis NE-SW caracterizadas por Frantz \& Remus (1986) e Philipp (1990, 1991). O modelamento gravimétrico da Zona de Cisalhamento Dorsal do Canguçu (Costa et al. 1994b) é compatível com a estrutura-em-flor positiva descrita por Philipp (1991) e Philipp et al. (1993). Fernandes et al. (1995b), com base na integração e reavaliação dos dados geolísicos disponíveis, propuseram a divisão do Escudo Sul-riograndense em três domínios geofísicos: domínios leste, central e oestc. Tais domínios são delimitados por expressivas discontinuidades gravimétricas e aeromagnetométricas.

Caracterização Estrutural A justaposição final das suítes graníticas do Batólito Pelotas é o resultado de movimentações sucessivas ocorridas ao longo das zonas de cisalhamento (dúctil e rúptildúctil). Estas suítes foram afetadas por três eventos de deformação (do mais antigo para o mais novo): $D_{1}, D_{2}$ e $D_{3}$ (Philipp 1990, 1991 e 1998, Fernandes et. al. 1990, 1992 a, 1993, Philipp et al. 1993).

$O$ evento $D_{1}$, preservado na SIPM, foi responsável pela geração de zonas de cisalhamento dúcteis de baixo ângulo com direção geral N35$50^{\circ} \mathrm{E}$ e mergulhos suaves para W. Nestas zonas, são observadas indicadores cinemáticos como pares de foliaçōes S-C, feldspatos e enclaves assimétricos, que indicam movimentação de topo para leste (Philipp 1990, 1991). Este quadro cinemático é coerente com a existência de lineações de estiramento mineral de caimento baixo ( 10 a $30^{\circ}$ ) para W (Figs. 3 e 4 ).

$O$ evento deformacional $D_{2}$ está preservado em todas suítes graníticas. Caracteriza-se pelo desenvolvimento de zonas de cisalhamento dúcteis de alto ângulo pervasivas por todo o batólito. São zonas de cisalhamento com extensão de dezenas a centenas de $\mathrm{Km}$ e espessura da ordem de centenas de metros. Nelas, as faixas de milonitos e protomilonitos podem chegar até cerca de $4 \mathrm{Km}$ de largura, como a Zona de Cisalhamento Arroio Grande (ZCAG), na região de Arroio Grande (Machado et al. 1995). A lineação de estiramento mineral possui caimento sempre baixo, contida numa foliação milonítica com mergulho subvertical, sugerindo para estas zonas movimentação essencialmente direcional. A geometria desta zona de cisalhamento é 


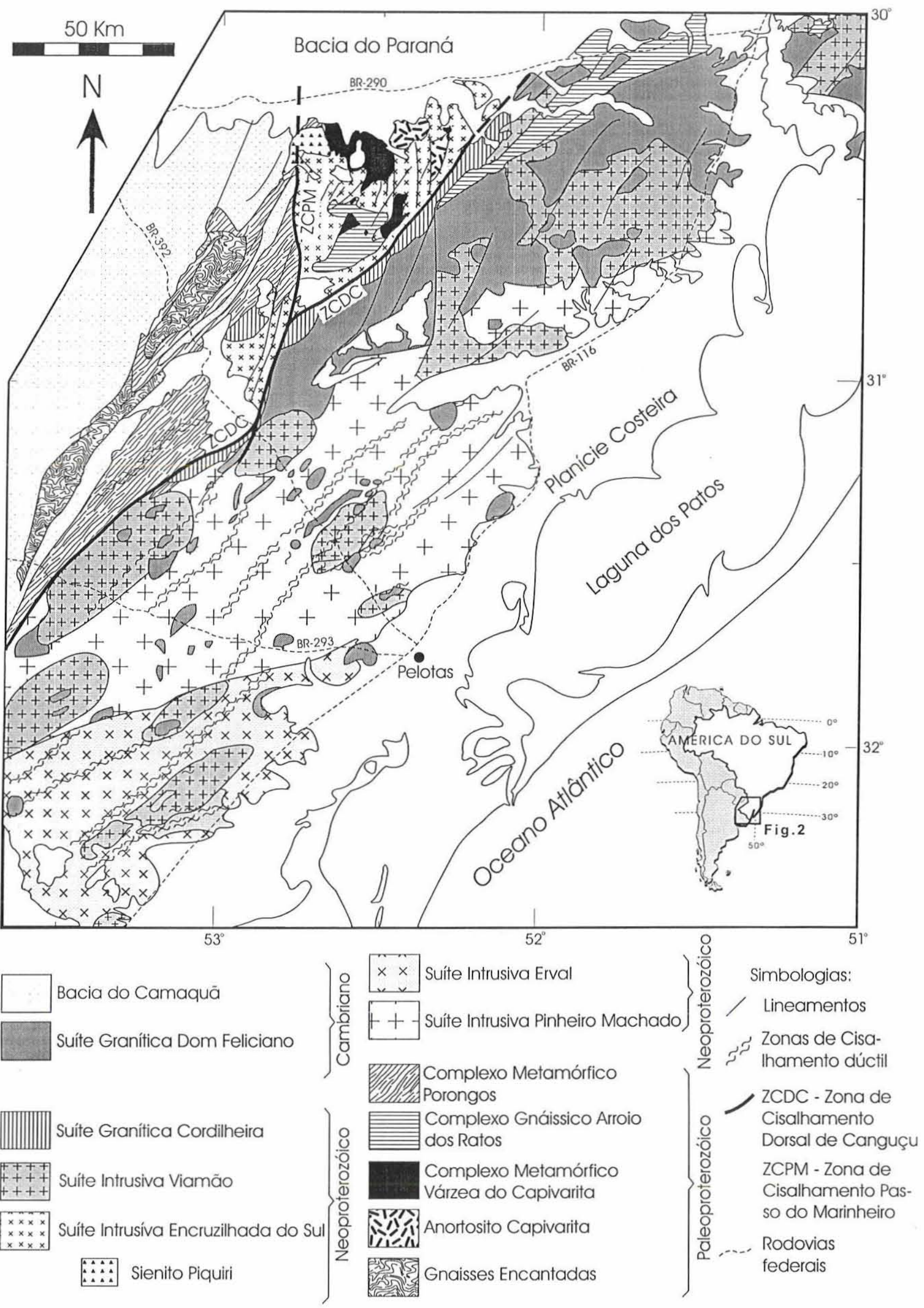

Figura 2. Mapa geológico do Batólito Pelotas com separaşão das suítes graníticas descritas no trabalho (extraído de Philipp 1998). 


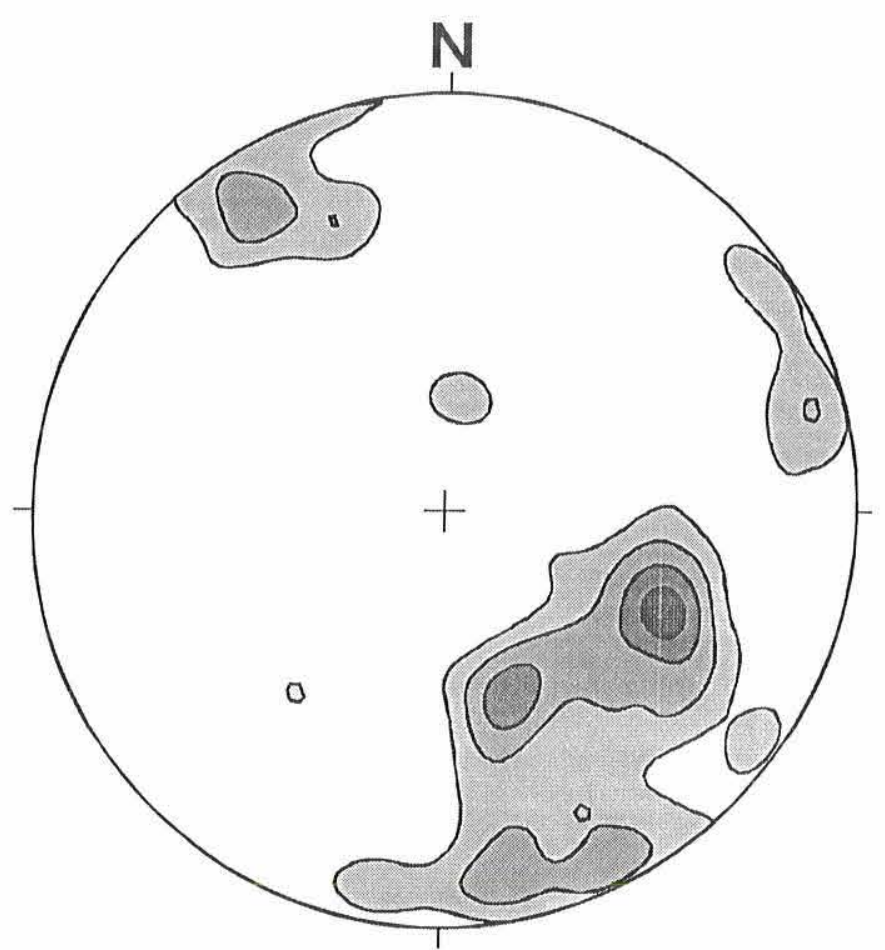

$N=175$

Contornos: $2,4,6$ e $8 \%$

Figura 3 - Estereograma de fiequiência (hemisfério inferior) dos pólos da foliaģão de baixo ângulo da Sunte Pinheiro Machado.

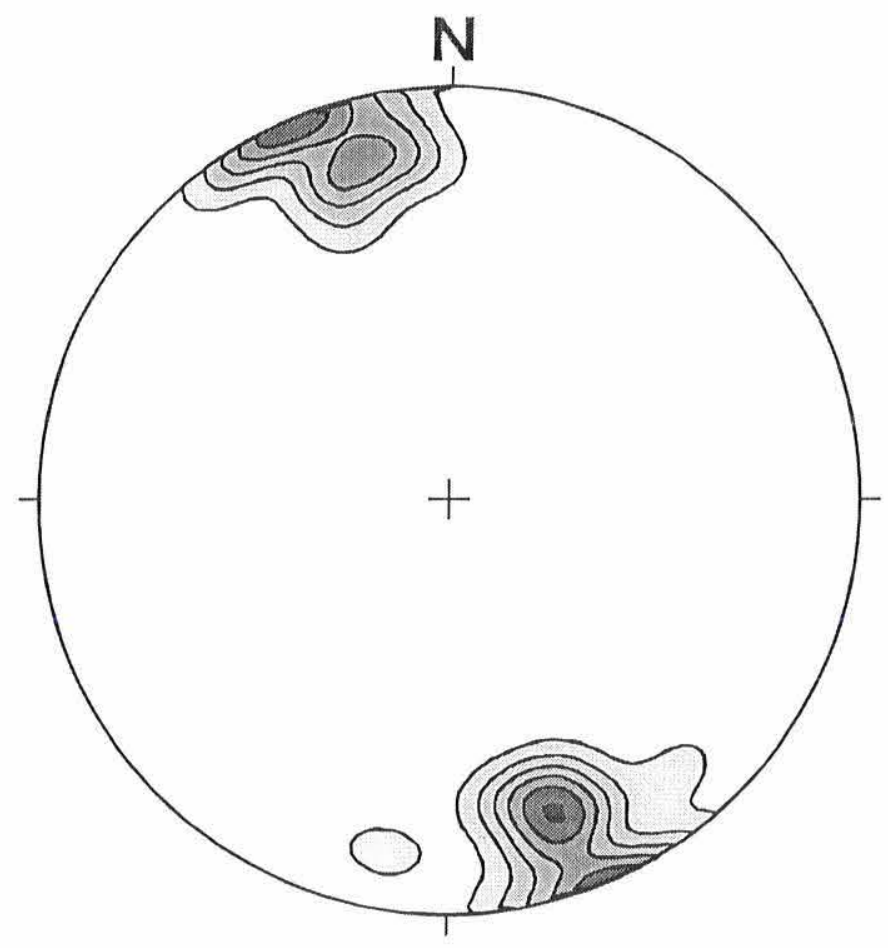

$\mathrm{N}=52$

Contorno:3,6,9,12,15,18\%

Figura 5 - Estereograma de frequiência (hemisfério inferior) dos pólos da folią̧ão milonítica da Zona de Cisalhamento de Arroio Grande.

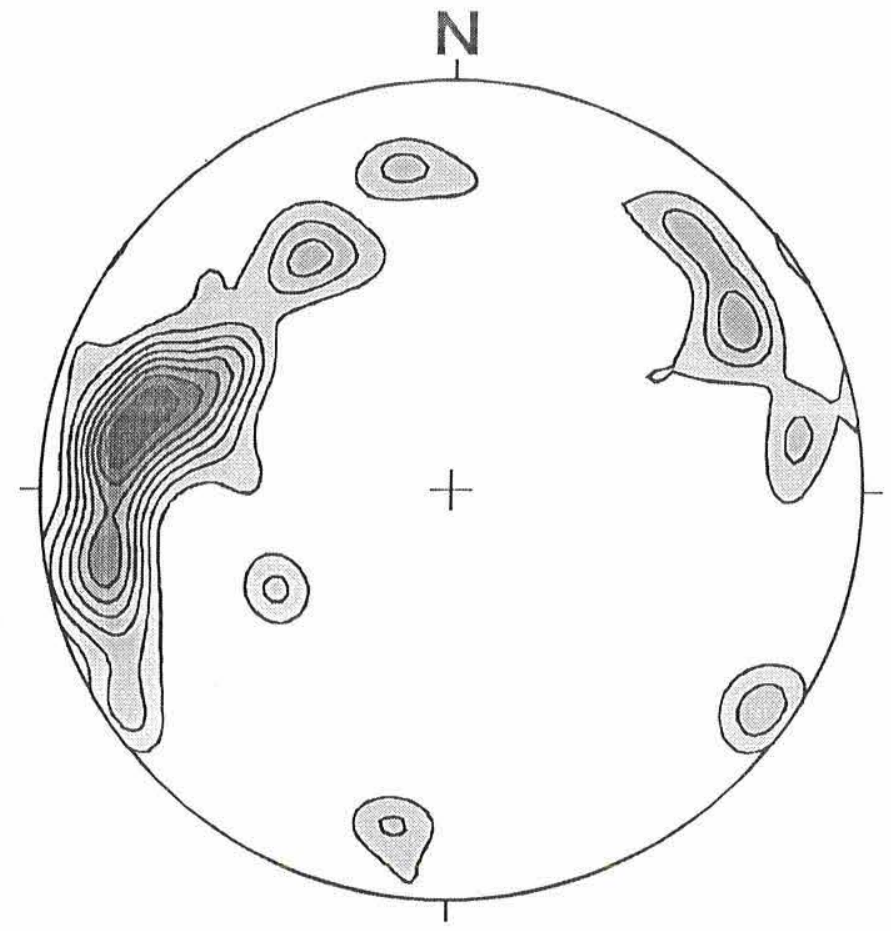

$N=225$

Contornos: $3,4,5,6,7,9 \%$

Figura t - Estereograma de fieqüiência (hemisfério inferior) das lineaçōes minerais das zonas de cisallamento de baixo ângulo da Sứte Pinheiro Machade.

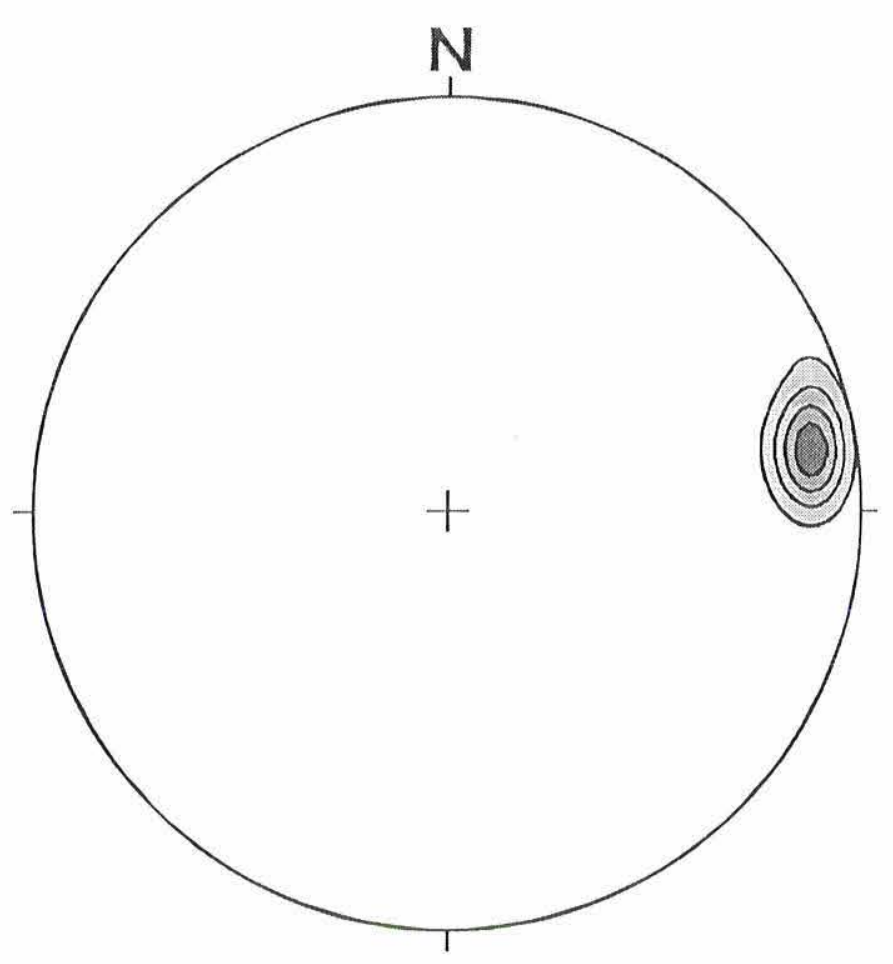

$N=18$

Contornos: $15,30,45,60 \%$

Figura 6-Estereograma de freçiêencia (hemisfério inferior) das lineações de estiramento mineral da Zona de Cisalhamento Arroio Grande.

Revista Brasileira de Geociências, Volume 31, 2001 
Ruy Paulo Philipp et al.

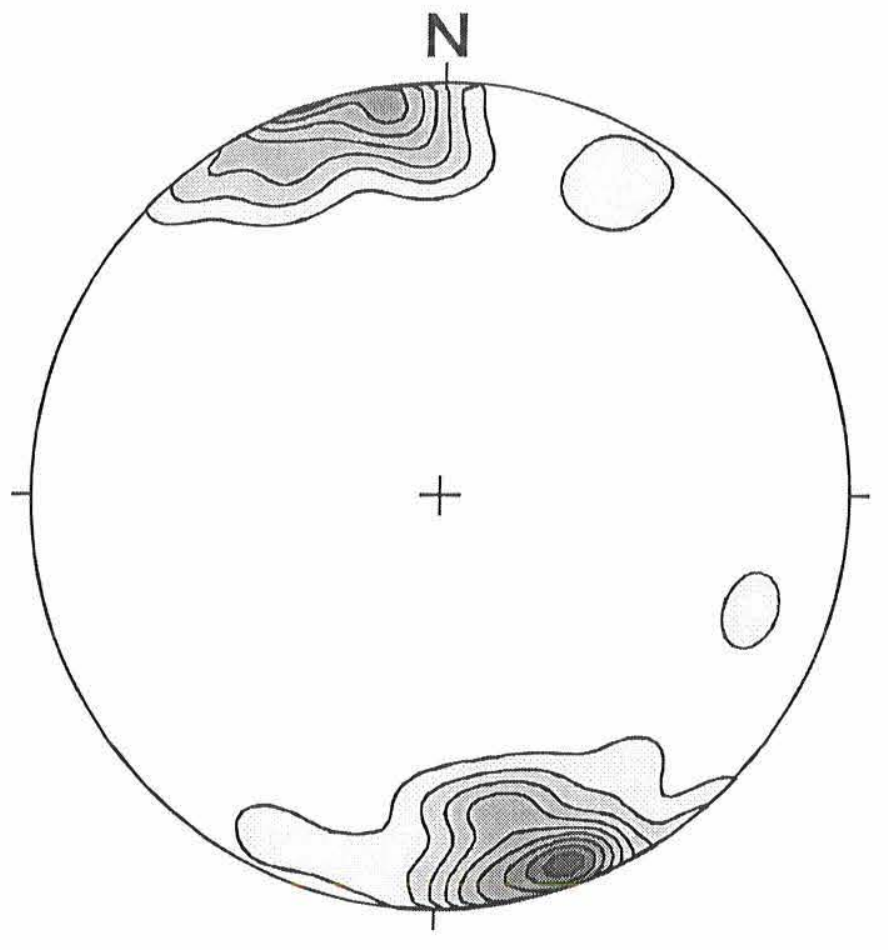

$N=35$

Contornos: $2,6,10,14,18 \%$

Figura 7 - Estereograma de frequiência (hemisfério inferior) dos pólos da foliação magmática do Granito Chasqueiro.

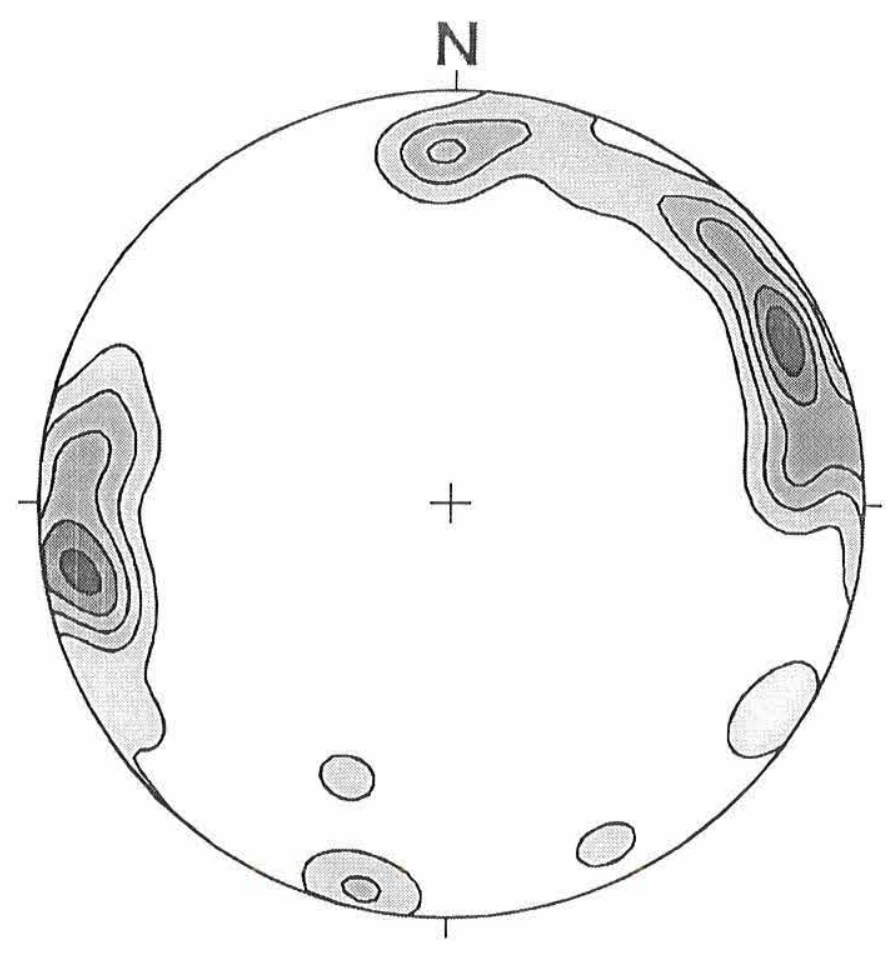

$\mathrm{N}=55$

Contornos: $2,4,6,8,10 \%$

Fïgura 9-Estereograma de freqüência (hemisfério inferior) dos pólos da foliașiono magmáitica do Granito Monte Bonito
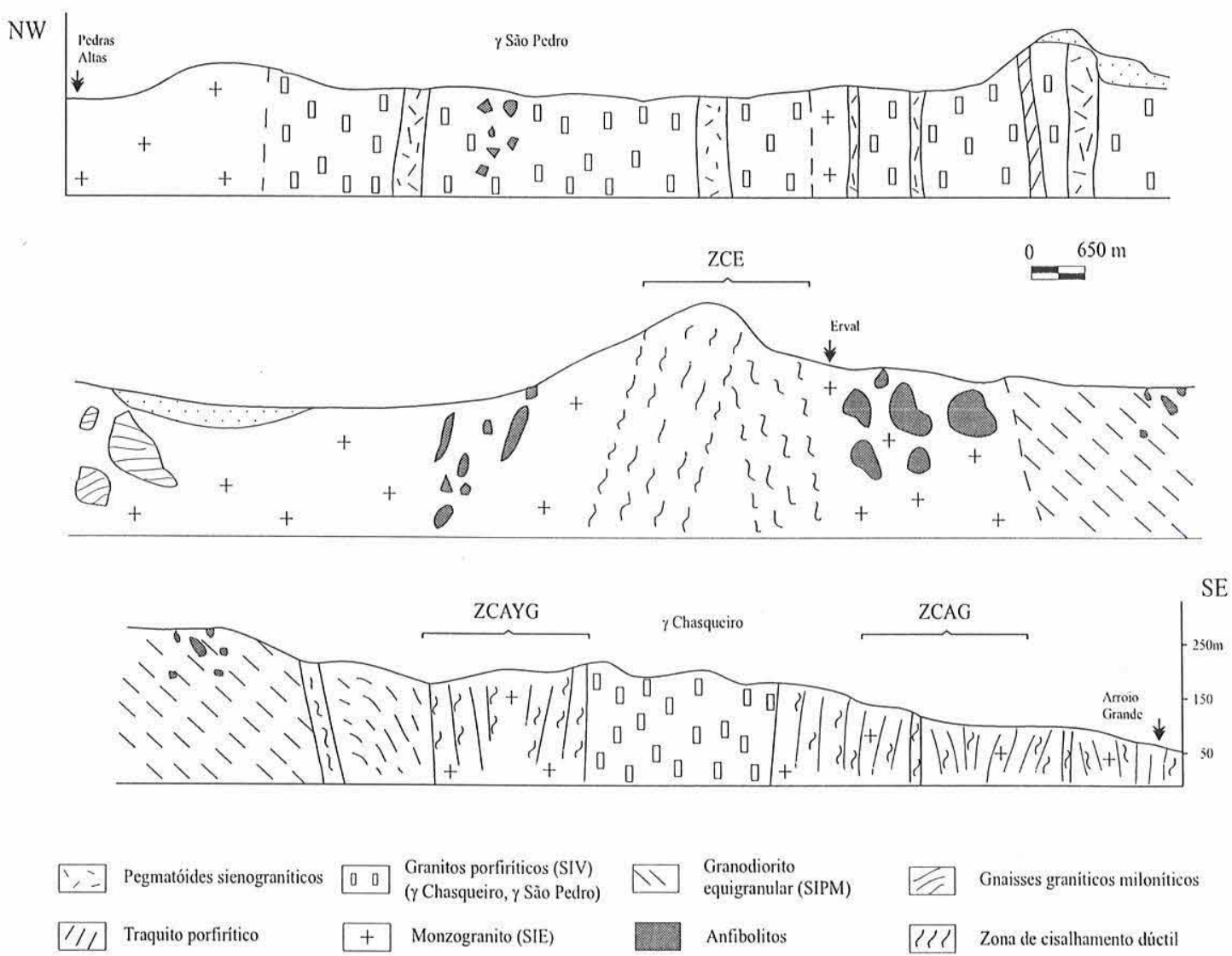

Figura 8-Perfil geológico Pedras Altas-Enval-Arroio Grande ( 60 Km de extensäo). ZCE-Zona de Cisalhamento Erval, ZCAYG-Zona de Cisalhamento Ayrosa Galvão, ZCAG-Zona de Cisalhamento Arroio Grande. 
de uma estrutura-em-flor positiva. As figuras 5 e 6 ilustram a relação geométrica entre estes elementos para a ZCAG. Para sul, esta estrutura parece conectar-se com a Zona de Cisalhamento Airosa Galvão (ZCAYG), conduzindo o afinamento do Granito Chasqueiro nesta mesma direção. A geometria da foliação magmática deste granito (Fig. 7) é concordante com a foliação milonítica da ZCAG (Fig. 5). Estes dados, juntamente com o perfil geológico mostrado na Figura 8, sugerem para este granito um modelo de alojamento controlado por esta estrutura-em-flor: Dados gravimétricos e de anisotropia de susceptibilidade magnética seriam necessários para uma melhor avaliação deste modelo. Nota-se ainda que os granitos peraluminosos correlacionáveis aos da SGC (Granito Três Figueiras, Philipp 1998) são também controlados pela ZCAG (Fig. 2).

Outra zona de cisalhamento importante na região, que se articula com as zonas anteriores, respondendo também pelo modelamento da porção sudeste do batólito, é a Zona de Cisalhamento de Erval. Com disposição subparalela à ZCAG, baliza grosseiramente o contato sul da SIPM e parece controlar a colocação do Granito Monte Bonito. A cartografia do maciço mostra uma concordância do seu cixo maior com a zona de cisalhamento (Fig. 2). Contudo, ao contrário do Granito Chasqueiro, a disposição da foliação magmática é oblíqua à orientação do granito (Fig. 9), sugerindo um alojamento concomitante à movimentação sinistral desta zona de cisalhamento e rotação das elipses de deformação na passagem do estado magmático para o estado sólido. A existência de zonas de cisalhamento destrais mais antigas do que zonas de cisalhamento sinistrais (Machado et cl. 1995), relacionadas aparentemente a quadros cinemáticos distintos, poderia ser um modelo favorável para explicar o alojamento deste maciço, pois a inversão cinemática propiciaria condições adequadas para a instalação de um regime extensional. Outro modelo possível para explicar o alojamento do maciço em questão é o modelo extensional de "relcasing bend" associado à regiões de inflexão de zonas de cisalhamento dúcteis de alto ângulo desenvolvidas em regime transpressivo. Neste modelo, a foliação magmática desenvolvida obliquamente às paredes das zonas de cisalhamento encaixantes é rotacionada, tornando-se paralelas à estas zonas com a progressão da deformação cisalhante, sobretudo nas bordas do corpo, região onde a deformação passa a ocorrer no estado sólido.

$\mathrm{O}$ evento $\mathrm{D}_{3}$, caracterizado por diversos autores como de natureza rúptil-dúctil, foi responsável pelo desenvolvimento de zonas de cisalhamento subverticais de menor expressão, com espessuras métricas a decamétricas, de orientação $\mathrm{N} 10-20^{\circ} \mathrm{E}$ a N6-80 $\mathrm{E}$. Estas zonas deslocam estruturas $\mathrm{D}_{2}$ e desenvolvem rochas miloníticas de baixa temperatura. Os indicadores cinemáticos observados nestas zonas ( $\mathrm{pa}-$ res de loliação S-C, bandas discretas de cisalhamento e estrias de atrito) sugerem cinemática principal sinistral. A existência de lineação de estiramento mineral subhorizontal, contida numa superfície de alto ângulo, é coerente com uma movimentação direcional. A Zona de Cisalhamento Passo do Marinheiro é uma estrutura relacionada à esta lase. Seguem-se movimentações e reativações posteriores, sobretudo do Permiano ao Triássico, $\mathrm{cm}$ condições essencialmente rúpteis, com geração de cataclasitos, relacionadas à evolução tectônica da Bacia do Paraná (Holz \& Philipp 1995).

CARACTERIZAÇÃO DAS SUÍTES GRANÍTICAS O Batólito Pelotas contém grande variedacle de xenólitos de rochas metamórlicas de alto e baixo grau, incluindo termos para e ortoderivados. A petrografia detalhada destas rochas permitiu uma comparação com as rochas encaixantes do batólito. Esta caracterização foi muito importante na avaliação da origem e colocação das suítes graníticas.

Septos do Embasamento São em geral restritos à escala de afloramento. Caracterizam-se por xenólitos de rochas metamórficas encontrados em todas as suítes graníticas do batólito, sugerindo a participação de crosta continental na geração do seu magmatismo. Na SIPM são encontrados xenólitos de gnaisses granodioríticos e tonalíticos, augen gnaisses, anlibolitos grano-nematoblásticos, gnaisses cálci-silicáticos, biotita-hornblenda anfibolitos finos bandados (para-anfibolitos), biotita gnaisses bandados (metapelitos) e ortognaisses migmatíticos (Philipp 1990, 1998). A leste de Piratini ocorrem xenólitos (mega) de ortognaisses (granodioríticos a tonalíticos), que foram designados Gnaisses Piratini (Fragoso Cesar et al. 1986).

A SIE contém xenólitos de rochas parametamórficas (baixo a médio grau), anfibolitos e ortognaisses subordinados. Destacam-se as exposições quilométricas dos Quartzitos e Xistos Erval (Fragoso Cesar et al. 1986), c os metacalcáreos, metamargas e anfibolitos Vilas Matarazzo e Pedreiras (Fragoso Cesar 1991; Philipp 1998).

A SIV contém xenólitos de ortognaisses e metagranitóides (miloníticos e ultramiloníticos). São descritas na região de Porto Ale-
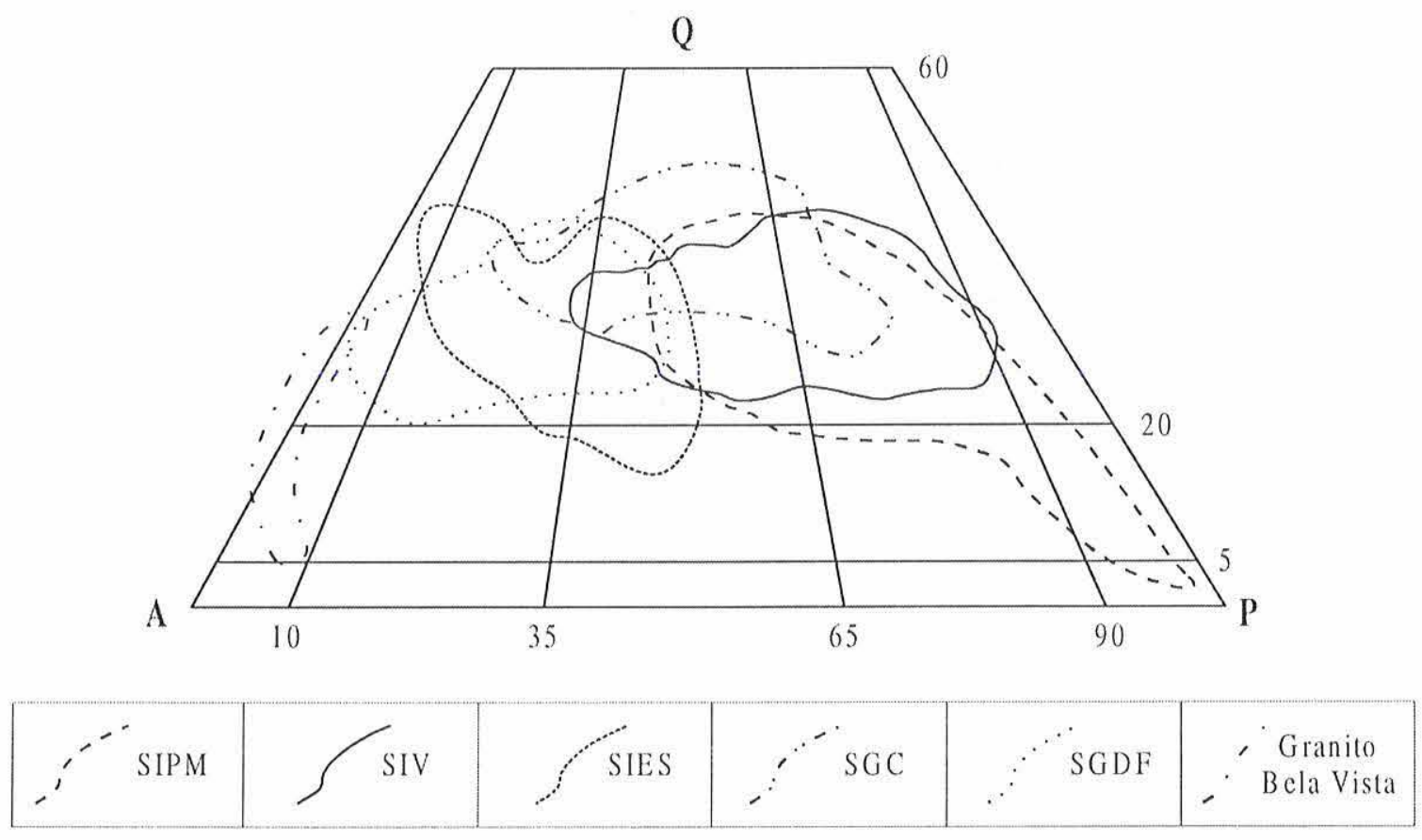

Figura 10 - Campo composicional das suítes graníticas do Batólito Pelotas segundo diagrama QAP de Streckeisen (1976). Fontes: Vasquez. (1997). Koester (1994) e Philipp (1998). 
gre exposições de metagranitóides (Gnaisses Porto Alegre, Philipp et al. 1998) com cerca de $2 \mathrm{Km}$ de extensão, que foram correlacionados por Philipp (1998) ao Complexo Gnáissico Arroio dos Ratos de Fernandes et al. (1990).

Na SIES são encontradas amplas exposições de paragnaisses aluminosos de alto grau, rochas cálci-silicáticas, quartzo-feldspáticas e mármores. Ocorrem também ortognaisses (granodioríticos a monzograníticos) e rochas básica e ultrabásicas associadas ao Anortosito Capivarita. Estas litologias foram inicialmente designadas de Formação Cambaí (Tessari \& Picada 1966), e redelinidas como Suíte Metamórfica Várzea do Capivarita (Frantz et cal., 1984) e Complexo Gnáissico Arroio dos Ratos (Fernandes et al. 1990), restringindo-se neste apenas as rochas ortoderivadas.

Suíte Intrusiva Pinheiro Machado (SIPM) Esta suíte ocupa uma faixa alongada na direção NE-SW na porção central do Batólito Pelotas e perfaz cerca de $30 \%$ de sua área (Fig. 2). Corresponde a suíte mais antiga do batólito e é a única que apresenta uma foliação de baixo ângulo atribuída ao evento $D_{1}$. Os granitóides da SIPM têm composição expandida, granodiorítica a monzogranitíca, com tonalitos, dioritos e quartzo-dioritos subordinados (Fig.10). São rochas de cor cinza, textura equigranular hipidiomórfica média a gros$\mathrm{sa}$, localmente inequigranular grossa, com megacristais tabulares de feldspato potássico $(1 \mathrm{e} 3 \mathrm{~cm})$, que perfazem de 1 a $3 \%$ da rocha. $\mathrm{O}$ plagioclásio é euédrico, de cor branca, com quartzo amebóide e biotita euédrica, esta última ocorrendo como agregados intersticiais. $\mathrm{O}$ feldspato potássico, subordinado, é intersticial. Os acessórios são zircão, allanita, apatita, titanita e minerais opacos.

O uso neste trabalho do nome SIPM, cm substituição ao Complexo Granítico Gnáissico Pinheiro Machado (Fragoso Cesar 1991), se deve à ampla preservação de texturas e estruturas magmáticas, cm diferentes escalas (macro e micro), pois as deformações no estado sólido nelas impressas são restritas às zonas de cisalhamento. A SIPM é cortada pela SIV, SGC e SGDF e ocorre como xenólitos nas SIE e SIV. A ocorrência de mistura heterogênea de magmas nesta suíte é indicada por enclaves microgranulares dioríticos e tonalíticos. Estes enclaves são arredondados a subarredondados, centimétricos, em contatos definidos, com limites curvos e lobados. A textura é equigranular hipidiomórfica fina a média $(0,5$ a $1,5 \mathrm{~mm})$, caracterizada por cristais prismáticos de plagiociásio e hornblenda, euédricos a subédricos, e biotita subordinada. Os acessórios são apatita, titanita e opacos.

Os dados Rb-Sr disponíveis para esta suíte apontam idades de 750 Ma (Teixeira 1982), $775 \pm 36 \mathrm{Ma}$ (Soliani Jr. 1986), $572 \pm 54 \mathrm{Ma}$ (May 1990) e de 830 a 800 Ma (Soliani Jr. 1986), este último obtido em xenólitos gnáissicos e migmatíticos. Estas são idades de referência, pois as isócronas incluem gnaisses do embasamento. Amostras representativas da suíte possuem razōes iniciais de ${ }^{87} \mathrm{Sr} /{ }^{86} \mathrm{Sr}$ entre $0,7060 \mathrm{e}$ 0,7068 . Idades U-Pb em zircão deram valores de $610 \pm 5 \mathrm{Ma}$ e $612 \pm$ $2 \mathrm{Ma}$ (Babinski el al. 1997). Estudos isotópicos de Sm-Nd, desenvolvidos por May (1990) e Babinski et al. (1997), indicaram para a SIPM idades modelo $\mathrm{T}_{\mathrm{DM}}$ entre 1636 e $2010 \mathrm{Ma}$, com valores de $\varepsilon_{\mathrm{Nd}}$ entre $5,6 \mathrm{e}-10$.

Suíte Intrusiva Erval (SIE) Esta suíte, definida por Philipp (1998), estende-se até o Uruguai e perfaz cerca de $20 \%$ da área do batólito. Ocorre na sua extremidade sul e apresenta forma alongada na direção NE-SW. Engloba maciços graníticos situados a sul do alinhamento estrutural que balisa as cidades Capão do Leão, Pedro Osório, Basílio e Pedras Altas (Fig.2).

As rochas desta suíte são homogêneas, textural e composicionalmente, com predomínio de monzogranitos e sienogranitos subordinados. Nos domínios não afetados pela deformação, apresentam estruturas magmáticas preservadas, como alinhamento de cristais euédricos de feldspatos numa textura equigranular hipidiomórfica. São granitos cinza claro, com plagioclásio prismático acinzentado, feldspato potássico subédrico branco a rosado, quartzo amebóide e biotita em lamelas euédricas intersticiais. Próximo de Arroio Grande ocorrem, no contato com mármores, zonas métricas de rochas sieníticas e quartzo-sieníticas com anfibólio e clinopiroxênio. Estas rochas são consideradas como produtos de assimilação da rocha carbonática pelo magma granítico. Isto ocorre também a leste de Erval, onde a assimilação de anfibolitos é responsável pela presença de anfibólio $\mathrm{cm}$ granitos da suíte.

Esta suíte acha-se intensamente afetada por zonas de cisalhamento de alto ângulo, dúcteis $\left(D_{2}\right)$ e rúptil-dúctil $\left(D_{3}\right)$. Dentre elas, destacamse: Zona de Cisalhamento Erval (ZCE), Zona de Cisalhamento Ayrosa Galvão (ZCAYG) e Zona de Cisalhamento Arroio Grande (ZCAG) (Machado et al. 1995). A ZCAG, com largura de cerca de $4 \mathrm{~km}$, é a mais importante delas e afeta sobretudo os granitos da SIE, desenvolvendo protomilonitos e milonitos de orientação N65-75'E. As ZCAYG e ZCE são caracterizadas por milonitos e ultramilonitos com orientação N50-60"E (Fig. 2).

A SIE contém xenólitos da SIPM e é intrudida pelas SIV (Granito Chasquciro) e SGDF.

Suíte Intrusiva Viamão (SIV) Philipp (1998) engloba nesta suíte os monzogranitos porfiríticos a inequigranulares, restringindo a denominação Suíte Granítica Dom Feliciano de Figueiredo et al. (1990) para os granitos equigranulares de composição sieno a álcalifelspato granítica. Os granitos da SIV distribuem-se por todo Batólito Pelotas, ocupando uma área de cerca de 15\% (Fig.2). São corpos alongados na direção $\mathrm{N} 40-50^{\circ} \mathrm{E}$, com extensão de 25 a $40 \mathrm{~km}$ e largura de 5 a $15 \mathrm{~km}$. Apresentam íntima relação com as zonas de cisalhamento de alto ângulo $D_{2}$. Fazem parte da suíte os granitos Viamão (Philipp 1998), Quitéria (Fernandes et al. 1990), Arroio Carajá, Barão do Triunfo, Cerro Grande (Ramgrab et al. 1996), Coxilha do Fogo (UFRGS 1995), Arroio Moinho (Gomes 1990), Monte Bonito (Philipp 1990), Chasqueiro e Quilombo (Trainini 1987), Independência (Schneider et al. 1974) e Arroio dos Kaster (Philipp 1998).

A figura 10 ilustra a variação composicional restrita da suíte, com monzogranitos, granodioritos e sienogranitos subordinados. As texturas são porfiríticas, também inequigranulares, grossas, com foliação ígnea e magmática definida pelo alinhamento de megacristais de feldspato potássico e lamelas de biotita. A concordância estrutural da foliação milonítica dos granitos da suíte com as zonas de cisalhamento de alto ângulo sugere para os mesmos um posicionamento sin a tardicinemático ao evento $\mathrm{D}$,

Os corpos graníticos estudados apresentam enclaves microgranulares dioríticos. São descritas misturas heterogênea de magmas (básico/intermediário a ácido), com diversos graus de contaminação (UFRGS 1995). Em alguns corpos, como o Coxilha do Fogo, na região de Canguçu, estes enclaves são muito expressivos, atingindo dimensões decamétricas. Nas zonas de contato, desenvolvem-se faixas transicionais de rochas híbridas, com gradações de termos granulares grossos (dioríticos, quartzo-dioríticos, tonalíticos e granodioríticos) para monzogranitos porfiríticos.

Os xenólitos de metagranitóides e de ortognaisses apresentam graus variáveis de assimilação pelo líquido granítico, resultando desta interação estruturas fantasmas, com bandamentos irregulares, definidos localmente por schlieren de biotita.

Os poucos dados isotópicos disponíveis para esta suíte apontam idades Rb-Sr de $572 \pm 22 \mathrm{Ma}$ (Granito Quitéria, Koester 1995) e U-Pb (em zircão) de $595 \pm 1 \mathrm{Ma}$ (Granito Arroio Moinho, Babinski et al. 1997), esta última correspondendo a sua idade de cristalização. Uma isócrona obtida em granitos desta suíte apresentou razão inicial ${ }^{87} \mathrm{Sr} /$ ${ }^{86} \mathrm{Sr}$ de 0,7052 . Os estudos isotópicos $\mathrm{Sm}-\mathrm{Nd}$ apresentam idades modelos entre 1275 e $1692 \mathrm{Ma}$, com valores de $\varepsilon_{\mathrm{Nd}}$ negativos $(-1,3$ a - - , 6) ( May 1990, Babinski et al. 1997).

Suíte Intrusiva Encruzilhada do Sul (SIES) A denominação dos granitóides desta suíte foi efetuada por Leinz et al. (1945), sendo redefinidos por Tessari \& Picada (1966) como Complexo Granítico Encruzilhada. Trabalhos recentes de mapeamento geológico se devem a Frantz et al. (1984) e Bitencourt et al. (1993a). Levantamentos integrados de estratigrafia, geoquímica e geocronologia foram efetuados por Vasquez (1997).

Os granitos desta suíte ocorrem na porção noroeste do batólito e perfazem cerca de 10\% de sua área. Abrangem os granitos Campinas, Pitangueiras, Encruzilhada e Pinheiros, os quartzo-sienitos e quartzomonzonitos Arroio dos Silva e o Sienito Piquiri (Vasquez 1997) (Fig. 
2). A suíte contém ainda enclaves microgranulares máficos diorítico e quartzo-diorítico, com indicação de intenso processo de mistura de magmas (ácidos, intermediários e básicos), resultando estruturas de mistura heterogênea e zonas de hibridização (Bitencourt et al. 1993a). Os enclaves mostram na matriz evidências de resfriamento rápido, com xenocristais em desequilíbrio, incluindo quartzo ocelar e feldspato potássico manteado pelo plagioclásio sódico, caracterizando assim textura rapakivi. Estas feições são encontradas nas zonas híbridas c margens resfriadas dos granitóides,.

Os corpos graníticos desta suíte se dispõem em uma faixa alongada na direção NE-SW, limitada a leste pela Zona de Cisalhamento Dorsal de Canguçu e a oeste pelo Complexo Cerro da Árvore. A Zona de Cisalhamento Passo do Marinheiro, com direção próxima de N-S, afeta os granitos desta suíte e exibe um deslocamento horizontal superior a $15 \mathrm{Km}$ (Fig. 2).

A composição da suíte varia de monzogranítica a álcali-feldspatogranítica, com megacristais tabulares de feldspato potássico em uma matriz com cristais prismáticos e euédricos de plagioclásio branco, biotita euédrica em agregados tipo "ninhos" e quartzo globular e euédrico, ocorrendo ainda anfibólio, zircão, apatita e opacos como minerais acessórios.

O Granito Encruzilhada é o maciço mais expressivo da suíte, sendo constituído por duas fácies principais: biotita granitos de textura porfirítica a inequigranular grossa, acinzentados a róseo acinzentados e alaranjados, e granitos rosados e acinzentados, equigranulares, grossos, de composição sienogranítica (Fig. 10). A fácies porfirítica, dominante, granodiorítica a monzogranítica, de matriz grossa, contém megacristais de feldspato potássico prismáticos euedrais de 3 a $8 \mathrm{~cm}$, que perfazem de 15 a $40 \%$ da rocha. A fácies equigranular é cortada por corpos tabulares de pegmatitos e aplitos com mineralizaçōes de $\mathrm{Sn}$ associadas à zonas de hidrotermalismo (Picada 1965).

São disponíveis idades Rb-Sr de $559 \pm 5$ Ma (Soliani Jr. 1986) e $581 \pm 16,8 \mathrm{Ma}$ (Vasquez 1997), respectivamente, e U-Pb de $594 \pm 5$ Ma (Babinski et al. 1997). Amostras representativas de granitos da suíte apresentam razão inicial ${ }^{87} \mathrm{Sr} /{ }^{86} \mathrm{Sr}$ entre 0,711 a 0,716 . Idades modelos $\mathrm{Sm}-\mathrm{Nd}$ obtidas no Granito Encruzilhada indicaram valores entre 1750 e $2080 \mathrm{Ma}$, com $\varepsilon_{\mathrm{Nd}}$ fortemente negativos ( - 11 a -15$)$ (Babinski et al. 1997).

Suíte Granítica Cordilheira (SGC) Os leucogranitos desta suíte ocorrem na extremidade oeste do Batólito e perfazem cerca de $5 \%$ de sua área (Fig. 2). São corpos alongados na direção $\mathrm{N} 45^{\circ} \mathrm{E}$, tabulares, concordantes com a Zona de Cisalhamento Dorsal de Canguçu e posicionados sintectonicamente em relação à mesma (Picada 1969 e 1971, Fernandes et al. 1990, Koester 1995 e Nardi \& Frantz 1995). São englobados na suíte os granitos Cordilheira (Picada 1965), Arroio Francisquinho (UFRGS 1993), Figueiras (Tessari \& Picada 1966) e Três Figueiras (Philipp 1998). Este último, ocorrendo na região de Arroio Grande, foi caracterizado como granito peraluminoso, de colocação sincrônica à ZCAG, reforçando assim a importância das zonas de cisalhamento dúcteis de alto ângulo $\left(D_{2}\right)$ no controle c posicionamento dos corpos da suíte.

A composição da SGC varia de sienogranítica a granodiorítica, com moscovita, biotita, turmalina, granada, monazita, zircão e minerais opacos (Fig. 10). Os corpos da suíte afloram extensamente desde a região de São Jerônimo-Quitéria até Pinheiro Machado. São granitos brancos a cinzentos, com pontuações escuras de biotita. A estrutura ć foliada, marcada nas zonas de baixa de deformação pela orientação de moscovita primária e biotita. A foliação possui duas orientações: uma suborizontal, magmática, com moscovita orientada, e outra subvertical, tectônica, sobretudo em regiões de alta deformação, nas bordas dos corpos, sendo associada às zonas de cisalhamento dúcteis. Os milonitos e protomilonitos contêm porfiroclastos assimétricos de feldspato potássico, plagioclásio e moscovita.

O Granito Três Figueiras é um corpo alongado na direçāo NE, de composição sieno a monzogranítica, tendo moscovita, feldspato potássico, plagioclásio e quartzo como minerais essenciais, biotita, granada e turmalina como acessórios. São comuns texturas protomiloníticas e miloníticas subordinadas.

São disponíveis idades Rb-Sr de $617 \pm 48 \mathrm{Ma}$ a $630 \pm 22 \mathrm{Ma}$, obtidas na região de Quitéria nos granitos Cordilheira e Arroio
Francisquinho (Koester 1995). A falta de dispersão dos pontos na isócrona e um elevado MSWD ( $>5$ ) tornam estas idades de baixo valor intepretativo. Soma-se, a isso, a existência de alteraçōes hidrotermais tardi-magmáticas e transformações metamórficodeformacionais promovidas pelas zonas de cisalhamento limítrofes destes corpos. A razão inicial ${ }^{87} \mathrm{Sr} /{ }^{86} \mathrm{Sr}$ de amostras representativas da suíte situa-se entre 0,7324 a 0,7406 .

Suíte Granítica Dom Feliciano (SGDF) Esta suíte é a mais jovem identificada no Batólito Pelotas. Apresenta composição próxima das SIV e SIES, diferenciando-se entretanto pelo seu caráter intrusivo nas demais suítes e pelo seu posicionamento tardio a posterior às zonas de cisalhamento $\mathrm{D}_{2}$. A SGDF ocupa cerca de $20 \%$ em área do batólito e ocorre principalmente na sua porção norte, fazendo contato a oeste com a SGC e o Complexo Gnáissico Arroio dos Ratos, enquanto a leste o contato é com a SIV e SIPM (Fig.2).

A SGDF caracteriza-se por uma grande homogeneidade composicional, estrutural e petrográfica, e presença restrita de enclaves, microgranulares e submicáceos. Sua principal ocorrência é um corpo lenticular orientado na direção $\mathrm{N} 50^{\circ} \mathrm{E}$, com cerca de $180 \mathrm{~km}$ de extensão e 15 a $45 \mathrm{~km}$ de largura. Estes corpos, embora alongados, mostram colocação posterior às zonas de cisalhamento $\mathrm{D}_{2}$, registrando apenas em alguns deles uma deformação dúctil incipiente.

Os granitos da suíte são rosados a castanho claro e esbranquiçados, com predomínio de composição sienogranítica (Fig.10). Os minerais essenciais são microclínio subédrico e quartzo amebóide, com biotita intersticial subeuédrica, entre 1 e $4 \%$. Os acessórios são allanita, zircão, titanita, apatita e minerais opacos, ocorrendo ainda fluorita, molibdenita (Porto Alegre) e galena (Amaral Ferrador). Em São Jerônimo, na região de Morrinhos, ocorrem greisens e biotititos mineralizados com cassiterita (Minuzzi, com.pes.).

Na porção norte de Dom Feliciano, as rochas desta suíte mostram contatos lobados com o Diorito Capim Branco, sugerindo assim relações de contemporaneidade com o mesmo.

A semelhança composicional e geoquímica da porção mais diferenciada desta suíte com os diques riolíticos e rochas tufáceas e piroclásticas de composição similar (Ana Dias e Asperezas), encontrados $\mathrm{em}$ várias regiões do batólito (Pedras Altas, Coxilha do Fogo, em Canguçu, Mariana Pimentel, Barão do Triunfo, Barra do Ribeiro e Porto Alegre), é sugestiva de uma vinculação genética entre os dois magmatismos (Philipp 1998).

Os dados Rb-Sr disponíveis para a SGDF forneceram idades de $572 \pm 10 \mathrm{Ma}$ (Cordani 1974), $550 \mathrm{Ma}$ (Teixeira 1982) e $547 \pm 17 \mathrm{Ma}$ para granitos e pegmatitos da cidade de Cristal, e $544 \pm 5$ Ma para o Granito Arroio dos Ladrōes ( Soliani Jr. 1990), $550 \pm 6$ Ma para os granitos equigranulares de Cristal e Dom Feliciano (Fragoso Cesar 1991) e $560 \pm 12$ Ma para os riolitos da Serra das Asperezas, em Pinheiro Machado (Soliani Jr. 1986). As razões iniciais de ${ }^{87} \mathrm{Sr} /{ }^{86} \mathrm{Sr}$ em amostras da suíte variam entre 0,7083 e 0,7140 . Os dados isotópicos $\mathrm{Sm}-\mathrm{Nd}$ mostram um amplo intervalo de idades modelo, entre 985 a $2919 \mathrm{Ma}$ (May 1990, Babinski et al.1997), com os valores de $\varepsilon_{\mathrm{N} d}$ negativos (entre $-0,3$ e $-9,5$ ).

\section{SIGNIFICADO TECTÔNICO E ORIGEM DO MAGMATISMO}

A integração das informações disponíveis sobre o Batólito Pelotas permitiu o reconhecimento de seis suítes graníticas, dispostas na seguinte ordem estratigráfica (da mais antiga para mais nova): Suíte Intrusiva Pinheiro Machado (SIPM), Suíte Intrusiva Erval (SIE), Suíte Intrusiva Viamão (SIV), Suíte Intrusiva Encruzilhada do Sul (SIES), Suíte Granítica Cordilheira (SGC) e Suíte Granítica Dom Feliciano (SGDF). Esta subdivisão estratigráfica foi baseada nos seguintes aspectos: (i) relações de contato entre as suítes; (ii) relações de enclaves; (iii) eventos deformacionais que afetam as suítes $\left(D_{1}, D_{2}\right.$ e $\mathrm{D}_{3}$ ) e (iv) variação composicional das mesmas.

A ocorrência de enclaves microdioríticos e áreas de rochas híbridas é indicativa da existência de processos de mistura de magmas básicos a intermediários associados ao magmatismo granítico da maioria das suítes do batólito. A SGDF é a única com escassez de enclaves (microgranulares e submicáceos). Possui composição próxima das SIV e SIES, porém é intrusiva nelas. A origem deste magmatismo básicointermediário é sugestivo de fonte mantélica.

Nas suítes do batólito ocorrem septos do embasamento, de origem orto e paraderivadas. São comuns na SIPM ortognaisses tonalíticos a monzograníticos e anfibolíticos, que ocorrem também nas SIV, SIE e SIES. Nestas duas últimas são encontradas ainda ocorrências expres- 
sivas de metassedimentos, que aparecem subordinadamente na SGC.

Os granitóides da SIPM se diferenciam dos demais pela sua ampla variação composicional e, principalmente, pelo conjunto de estruturas primárias e tectônicas associadas. Fora das zonas de mais alta de deformação, as rochas apresentam bandamento de fluxo ígneo irregular c descontínuo, marcado por schlierens biotíticos. Na presença de xenólitos de ortognaisses, anfibolitos e paragnaisses, ocorre o desenvolvimento de uma estrutura planar pronunciada, onde é possível observar vestígios de diferentes estágios de assimilação. A transformação metamórfica associada às zonas de cisalhamento $\mathrm{D}_{1}$, restritas à esta suíte, é caracterizada pela ampla recristalização do quartzo e feldspato de potássio em mosaicos granoblásticos, equigranulares c inequigranulares, com subgrãos e neocristalização local de plagioclásio, e segregação de níveis finos de biotita, moscovita, titanita e opacos. As texturas e paragêneses metamórficas associadas à estas zonas foram desenvolvidas em condições metamórlicas compatíveis com a fácies anfibolito inferior a médio.

Zonas de cisalhamento subverticais $\left(D_{2}\right)$ afetam as estruturas magmáticas e tectônicas anteriores, promovendo o desenvolvimento de nova uma trama estrutural. Nos granitóides da SIPM ocorre o dobramento da foliação de baixo ângulo e lineações associadas, bem como geração de rochas miloníticas nas zonas de cisalhamento de alto ângulo. As microestruturas geradas neste evento incluem recristalização do quartzo em agregados granoblásticos inequigranulares, encurvamento das maclas de feldspatos e deformação rúptil dos mesmos. Este processo foi acompanhado pela quebra do feldspato de potássio $\mathrm{em}$ mica branca de granulação fina, juntamente com formação de epídoto e carbonato. As feições petrográficas observadas nas rochas miloníticas são compatíveis com condições de fácies xisto verde.

O restrito intervalo composicional e a composição extremamente diferenciada da SGDF é compatível com a fase de evolução final do magmatismo do Batólito Pelotas.
A constituição do Batólito Pelotas encontra-se relacionada a distintos processos tectônicos. As altas razões isotópicas de ${ }^{87} \mathrm{Sr} /{ }^{86} \mathrm{Sr}$ e os valores negativos de $\varepsilon_{\mathrm{va}}$ são compatíveis com uma origem por reciclagem crustal para o magmatismo do batólito, indicando participação subordinada de material juvenil.

Os dados disponíveis sobre a SIPM mostram grande semelhança com granitóides de margem continental ativa. Estas características sugerem para a suíte uma evolução associada a subducção de uma crosta oceânica sob uma margem continental espessada, com geração de um arco magmático pré-colisional do tipo Cordilherano. Segue-se um magmatismo colisional, como indicado pelas características composicionais e estruturais apresentadas pelas SIE, SIV, SIES e SGC. Além da restrita variação composicional, tais suítes apresentam em grande parte uma evolução associada ao desenvolvimento de zonas de cisalhamento dúctcis de alto ângulo, sendo nelas significativa a presença de magmatismo básico associado.

Apesar da restrita variação petrográlica e da composição cálcio-alcalina alto-K, o magmatismo pós-colisional representado pela SGDF mostra uma porção reduzida de granitos e rochas vulcânicas de composição alcalina. O controle exercido pelas zonas de cisalhamento rúpteis no nível de colocação destes maciços graníticos sugere que as porções mais inferiores destas zonas atingiram provavelmente a porção basal da crosta ou mesmo o manto litosférico, produzindo descompressão adiabática e fusão parcial. A presença de rochas alcalinas e de granito peralcalino marca a transição do regime colisional para o de estabilização da porção leste do escudo sul rio-grandense.

Agradecimentos À FAPESP (Proc. 94/5952-7) e à FAPERGS (Proc. 99-1975.9) , pelo suporte financeiro que permitiu a realização dos trabalhos de campo, ao CNPq (Proc. 300423/82-9, de R. Machado), pela concessão de uma bolsa de Produtividade em Pesquisa, c a dois revisores anônimos pelas valiosas contribuições ao trabalho.

\section{Referências}

Almeida F.F., Hasui Y., Brito Neves B.B., Fuck R.A. 1981. Brazilian Strucutural Provinces: An Introduction. Earth Science Reviews. 17:1-29.

Babisnki M.. Chemale Jr. F., Van Schmus W. R., Hartmann L.A.. Silva L.C. 1997. U-Pb and $\mathrm{Sm}-\mathrm{Nd}$ geochronology of the Neoproterozoic Granitic-Gneissic Dom Feliciano Belt. Southern Brazil. Journal of South American Earth Science, 10 (3-4):263-274.

Bitencourt M.F., Gastal M.C.P., Kirchein R.E., Costa K.B., Toledo F.A.L. 1993. Reavaliaçẫo preliminar das relaçōes estratigráficas do Complexo Granítico Encruzilhada (CGE), RS. In: Simpósio Internacional del Neoproterozóico-Cambrico de la Cuenca del Plata, L. Las Palomas-Minas, Boletim de Resumos Expandides, v.2. n" 34. $6 \mathrm{p}$.

Carvalho P.F. de. 1932. Reconhecimento Geológico do Rio Grande do Sul, Rio de Janeiro. Boletim do Instituto Geológico de Minerạ̧äo Brasileira. 66:1-72.

Chemale Jr. F. Hartmann L.A.. Silva L.C. 1994. Tectonic evolution of Southern Brazil in the Brasiliano Cycle. In: SBG. Congresso Brasileiro de Geologia. 38. Camboriú. Bolctin de Resumes Expandidos. 1: 626.

Chemale Jr. F \& Babinski M. 1995. U.Pb zircon dating of deformational events from the Neoproterozoic rocks in the Eastern Brazil. Simpósio Nacional de Estudos Tectônicos. V, Gramado, Boletim de Resumess Expandidess, 377-378.

Chemale Jr. F.. Babinski M., Van Schmus W.R., Wildner W., Lima E.1: 1997. U-Pb and Sm$\mathrm{Nd}$ isotopic studies of Neoproterozoic to early Paleozoic belts in southern Brazil. In: SBG. South-American Symposium on Isotope Geology, São Paulo. Boletim de Resumos Expandidos, 71.

Cordani U.G.. Halpern M.. Berenhole M. 1974. Comentários sobre as determinações geocronológicas da folha Porto Alegre. In: Carta Geolóngica do Brasil ao Milionésimo, folha Porto Alegre (SH-22) e folha Lagoa Mirim (SI-22), Brasilia, DNPM. Ministério das Minas e Energia. p.70-84.

Costa A.FU \& Caldasso A.L.S. 1994a. Padrôes do campo magnético aplicados à geologia estrutural na regiāo de Pinheiro Machado, RS. In: SBG. Congresso Brasileiro de Geologia. 38. Camboriú. Boletim de Resumos Expandides, 2:31-32.

Costa A.F.U., Fernandes L.A.D.. Magro F.H.S., Nadal C.A.. Félix L. 1994b. Modelo gravimétrico da Zona de Cisalhamento Dorsal de Canguçu. In: SBG, Congresso Brasileiro de Geologia, 38. Camboriú, Boletim de Resimmos Expandidos. 2:28-30.

Costa A.F.U. \& Ramgrab G. 1989. Lineamento Jaguarão: caracterização aeromagnética. Rerista Brasileira de Geofisica, 7(1): 41-45.

Fernandes L.A.. Tommasi A.. Porcher C.C. 1990. Esboço estrutural de parte do Batólito Pelotas. região de Quitéria-Capivarita. Acta Geológica Leopoldensia, 30:117-138.

Fernandes L.A., Tommasi A.. Porcher C.C. 1992a. Deformation patterns in the southern Brazilian brach of the Dom Feliciano Belt: a reappraisal. Jomrnal of Somth American Earth Science, 5(1):77-96
Fernandes L.A.D., Tommasi A., Porcher C.C., Koester E., Kraemer G., Scherer C.M.S Menegat R. 1992b. Granitóides brasilianos precoces do Cinturīo Dom Feliciano. Caracterização geoquímica e discussão estratigraifica. Pesquisas. 19(2):197-218

Fernandes L.A.D., Tommasi A., Vauchez A., Porcher C.C., Menegat R., Koester E. 1993. Zona de Cisallıamento Transcorrente Dorsal de Canguçu: caracterizaçâo e importância na compartimentaçâo tectônica do Cinturâo Dom Feliciano. Revista Brasilecira de Geociências, 23(3):224-233.

Fernandes L.A.D., Menegat R., Costa A.F.U., Koester E., Porcher C.C., Tommasi A. Kraener G., Ramgrab G.E., Camozzato E. 1995a. Evolução Tectônica do Cinturão Dom Feliciano no Escudo Sul-Rio-Grandense: Parte I - uma contribuiçióo a partir do registro geológico, Revista Brasileira de Geociências, 25(4):375-384.

Fernandes L.A.D. Menegat R. Costa A.F.U., Koester E., Porcher C.C.. Tommasi A. Kraemer G. Ramgrab G.E., Camozzato E. 1995b. Evolução Tectônica do Cinturầ Dom lecliciano no Escudo Sul-rio-grandense: Parte II - uma contribuiçâo a partir das assinaturas geofisicas. Revista Brasileira de Geociências. 25(4):375-38-

Figueiredo M.C.H.. Fragoso Cesar A.R.S., Kronberg B.L. 1990. Litogeoquímica das proncipais unidades do Batólito Pelotas no Rio Grande do Sul. In: SBG, Congresso Brasileiro de Geologia, 36, Natal, Anais, 4:1623-1738.

Fragoso Cesar A.R.S. 1980. O Cráton do Rio de La Plata e o Cinturão Dom Feliciano no Escudo Uruguaio-Sul Riograndense. In: SBG, Congresso Brasileiro de Geologia, 31, Camboriú, Anais, 5:2879-2891.

Fragoso Cesar A.R.S. 1991. Tectônica de Placas no Ciclo Brasiliano: As orogenias dos Cinturões Dom Feliciano e Rilcira no Rio Grande do Sul. Instituto de Geociências. Universidade de São Paulo, São Paulo. Tese de Doutoramento, 362p.

Fragoso Cesar A.R.S. 1993. As placas brasilianas do sul e sudeste da Plataforma Sul-Americana. In: SBG, Simpósio Nacional de Estudos Tectônicos. IV. Belo Horizonte. Boletim de Resumos Expandidos,12:183-187.

Fragoso Cesar A.R.S. Fïgueiredo M.C.H., Soliani Jr. E., Faccini U.I. 1986. O Batólito Pelotas (Proterozóico Superior/Eo-Paleozóico) no Escudo do Rio Grande do Sul. In: SBG, Congresso Brasileiro de Geologia, 34, Goiânia. Anais, 3:1322-1343.

Fragoso Cesar A.R.S, Machado R., Philipp R.P., Mello F.M., Endo I., Nummer A.R. Preciozzi F.P. Fambrini G.L., Sayeg H.S. 1998. Terrenos Suspeitos a sul da Placa Sanfranciscana (SE da Plataforma Sul-americana). In: Sociedade Uruguaia de Geologia, Congresso Uruguaio de Geologia, II, Punta del Este, Alas, 1-16.

Frantz J.C., Lima E.F. Machado R.P., Naumann M. 1984. Contribuiçâo a geologia de Encruzilhada do Sul-RS. In: SBG, Congresso Brasileiro de Geologia. 33, Rio de Janeiro, Anais, 5:2407-2416

Franty J.C. \& Remus M.V.D. 1986. Geologia da região de Canguçu-Torrinhas. RS: caracterizaç̧âo petrográlica, estrutural e estratigráfica. In: SBG. Congresso Brasileiro de Geologia, 34. Goiania. Anais, 2:931-947. 
Frantz J.C. \& Nardi L. V.S. 1992a. Litoquímica e evolução de Granitóides Cálcico-Alcalinos da região leste do Escudo Sul-rio-grandense. Pesquisas, 19(1):13-25.

Frantz J.C. \& Nardi L.V.S. 1992b. O magmatismo granítico da região Oriental do Escudo Sul-rio-grandense. Uma revisão, Pesquisas, 19(2):183-189.

Gomes M.E. B. 1990. Petrologia do Granito Arroio Moinho, Camguçu (RS): geoquímica e deformascūo. Instituto de Geociências, Universidade Federal do Rio Grande do Sul, Porto Alegre. Dissertação de Mestrado, 199p.

Goni J.C.. Goso H., Issler R.S. 1962. Estratigrafia e geologia econômica do PréCambriano e do Eo-Paleozóico Uruguaio e Sul-riograndense. Porto Alegre, Publicação Avulsa da Escola de Geologia. Universidade Federal do RS, 3:1-105.

Hallinan S.E., Mantovani M.S.M.. Shukowski W.., Braggion Jr. I. 1993. Estrutura do Escudo Sul-brasileiro: uma revisão através de dados gravimétricos e magnetométricos. Rerista Brasileira de Geociências, 23(3):201-214.

Hartmann L.A., Chemale Jr. F. Silva L.C. 1994. Mantle plume tectonics in the Brasiliano Cycle of the Dom Feliciano Belt. Southern Brazil. In: SBG. Congresso Brasileiro de Geologia. 38, Camboriú. Boletim de Resumos Expandidos. 1:623.

Hasui Y., Carneiro C.D.R., Coimbra A.M. 1975. The Ribeira Folded Belt. Rerista Brasileira de Geociências, 5(4):257-266.

Holz M. \& Philipp R.P. 1995. Estratigrafia de sequências e controle tectônico: um exemplo na borda leste da Bacia do Paraná no Rio Grande do Sul. In: SBG. Simpósio Nacional de Estudos Tectônicos, V, Gramado, Botetim de Resumos Exyandidess, 28+-286.

Jost H. 1981. Geology and Metallogeny of the Santana da Boa Vista region, South Brazil. University of Athens, Georgia, PhD Thesis, 208p.

Jost H. \& Hartmann L.A. 1984. Província Mantiqueira, In: Almeida FF.M. \& Hasui Y. (ed.) O Pré-Cambriano do Brasil. Rio de Janeiro, Edgar Blucher, 345-368.

Koester E. 1995. Petrologia e Geocronologia dos Granitóides Sintectônicos à Zona de Cisalhamento Dorsal de Canguşu. Porto Alegre, Instituto de Geociências, Universidade Federal do Rio Grande do Sul, Dissertação de Mestrado, 240p.

Leinz V. \& Pinagel H. 1945. Estanho e Tungstênio no Rio Grande do Sul, Rio de Janeim. Boletim da Divisĩo de Fomento a Produçâo Mineral, 70:1-80.

Machado R.. Philipp R.. Mello F. 1995. Reconhecimento de zonas de cisalhamento dúcteis de alto ângulo com cinemática superposta na extremidade sul do Batólito Pelotas. RS. In: SBG, Simpósio Nacional de Estudos Tectônicos, V. Gramado, Boletim de Resumos Expandides. 52-53.

Marques J.C., Jost H., Roisenberg A., Frantz J.C. 1998. Rochas metassedimentares, geologia estrutural e metamorfismo da Suíte Metamórfica Porongos na área da Antiforme Capané, Cachocira do Sul - RS. Rèrista Brasilecira de Géociênciass, 28(4): 467-472.

Masquelin H. 1989. Analisis estructural de las zonas de cizalla en las migmatitas de Punta del Este. Uruguay. In: SBG. Simpósio Sul-Brasileiro de Geologia, IV. Porto Alegre, Boletim de Resumos Expandidos, 35-37.

May G.E. 1990. Pan-African magmatism and regional tectonics of South Brasil. Open University, Milton Keynes, Ph.D. Thesis, 343p.

Mesquita M.J.M. \& Fernandes L.A.D. 1990. Petrografia dos granitóides deformados na Zona de Cisalhamento Dorsal de Canguçu (região de Quitéria-Capivarita). Acta Geológica Leopoldensia. 30:55-74.

Mesquita M.J.M. 1991. Petrografia dos granitóides deformados na Zona de Cisallhamento Dorsal de Canguçu (Piratini - Quitéria), RS. Instituto de Geociências, Universidade Federal do Rio Grande do Sul, Porto Alegre, Dissertição de Mestrado, 242p.

Nardi L.V.S. 1991. Caracterização petrográfica e geoquímica dos granitos metaluminosos da associação alcalina: uma revisĩo. Pesquisas, Porto Alegre, 18(1):44-57.

Nardi L.V.S. \& Frantz J.C. 1995. The Cordilheira Intrusive Suite: Late Proterozoic peraluminous granitoids from the southern Brazil. Journal of South American Earth Sciences, 8(1):55-63.

Philipp R.P. 1990. Geologia e Petroquímica dos granitóides da regiāo de Monte Bonito. Pelotas, RS. Instituto de Geociências, Universidade Federal do Rio Grande do Sul. Porto Alegre. Dissertaçĩo de Mestrado. 23Ip.

Philipp R.P. 1991. Geologia dos granitóides da regiâo de Monte Bonito, Pelotas. RS: uma contribuição ao reconhecimento estratigráfico do Setor Oriental do Escudo SulRiograndense. Acta Geológica Leopoldensia. v.XIV, 33:71-128.

Philipp R.P. 1998. A Evoluşāo Geológica e Tectônica do Batólito Pelotas no Rio Grande do Sul. Instituto de Geociências, Universidade de São Paulo, Sĩo Paulo, Tese de Doutorado, 255p.

Philipp R.P., Almeida D.P.M., Gomes M.E.B., Pintaúde D.A. 1991. Geoquímica do Granito Bela Vista, Piratini. RS: uma contribuiçâo ao conhecimento do magmatismo alcalino no setor Oriental do Escudo. Acta Geolégica Leopoldensia, v. XIV, 34:95-122.
Philipp R.P., Mesquita M.J., Gomes M.E.B., Almeida D.P.M. 1993. Reconhecimento estrutural e geoquímico dos Granitóides Brasilianos da região de Pelotas, RS. Pesquisus. $20(1): 3-13$.

Philipp R.P., Nardi L. V.S., Machado R. 1998. O Magmatismo Granítico Neoproterozóico tardi a pós-colisional da região de Porto Alegre, RS. In: Contribuição ao Estudo dos Grunitos e Rochas Correlatas. Bahia, Publicaçâo Especial n5, Sociedade Brasileira de Geologia, Núcleo Bahia-Sergipe, 129-152.

Picada R.S. 1965. Ocorrências de migmatitos, granitos e graisens controlados por fraturas regionais, Encruzillacela do Sul, RS. Boletim da Escola de Geologia da UFRGS, Porto Alegre, 14:7-59.

Picada R.S. 1969. Faixa de granitos sincinemáticos no Escudo Sul-Riograndense. In: SBG, Congresso Brasileiro de Geologia, 22, Salvador, Resumo das Comumicaşũes, $\mathrm{n}^{\circ} 86$.

Picada R.S. 1971. Ensaio sobre a tectônica do Escudo Sul-riograndense. In: SBG. Congresso Brasileiro de Geologia, 25, São Paulo, Anais. 1:167-191.

Ramgrab G.E., Wildner W.. Camozzato E. 1996. Mapa Geolúgico da Folha Porto Alegre SII.22-Y-B. Brasilia, CPRM, Programa de Levantamentos Geológicos Básicos, 1 Hp.

Ribeiro M. 1977. Mapa geológico da quadrícula de Piratini. RS. Fundação Zoobotânica do RS, Publicaçâo Especial no 2, escala 1:50.000, Porto Alegre.

Ribeiro M. \& Fantinel L.M. 1978. Associaçōes petrotectônicas do Escudo Sul-Riograndense : I -Tabulação e distribuiçâo das associnçōes petrotectônicas do Escudo do Rio Grande do Sul. Theringia, Série Geológica, 5:19-54.

Schneider A. W., Loss E.L., Pinto J.F. 1974. Mapa geológico da Folla Porto Alegre, RS. Porto Alegre, CNPq.

Shukowsky W. \& Mantovani M.S.M. 1991. Estruturação dos terrenos Pré-Cambrianos da região sul do Brasil e oeste do Uruguai: um estudo por modelamento gravimétrico. Revista Brasileira de Geofisica, 9(2):275-287.

Silva L.C., McNaughton N.J., Hartmann L.A., Fletcher I.R. 1997. U-Pb (SHRIMP) geocronology in the Camboriu Conplex and other gneisses from the basement of the Neoproterozoic southern Brazilian Granitic province, Brazil. In: SBG, International Symposium of Granitic Rocks and Associated Mineralization, II., Salvador, Boletim de Resumos Expandidos, 278-279.

Sobanski A.F., Rogge J.II., Marques D.H., Parmeggiani M. 1989. Projeto Rodeio Norte, RS - Faixa IV. Departamento de Geologia, Universidade do Vale do Rio dos Sinos, São Leopoldo. Trabalho de Graduaçâo do curso de Geologia, 152p.

Soliani Jr. E. 1986. Os dados geocronológicos do Escudo Sul-rio-grandense e suas implicasoùes de ardem geotectônicu, Instituto de Geociências. Universidade de São Paulo, Sĩo Paulo. Tese de Doutoramento, 425p.

Streckeisen A. 1. 1976. To each plutonic rock its proper name. Earth Scicnce Rewien: 12:133.

Teixeira IV. 1982. Follhas SH.22-Porto Alegre, S1.22 - Lage Mirime SH.21 - Unuguaiano Interpretação dos dados radiomérricos e evolução geocronológica. Florianópolis. Projeto RADAMBRASIL., Relatónio Interno.

Tessari R.I. \& Picada R.S. 1966. Geologia da Quadrícula de Encrusilhada do Sul, RS Boletim do DNPM/DFPM, 12+:1-147.

Tessari R. \& Giffoni L.E. 1970. Geologia da regiāo de Piratini. Pinheiro Machado e Bagé, RS. Boletim do DNPM/DFPM, 246:1-122.

Trainini D.R. 1987. Projeto Mapas metalogenéticos e de previsāo de recursos minerais. Follaws SI-22 Jaguarão-Rio Grande. Porto Alegre, DNPM/CPRM, 2vol.

UIRGS. 1993. Mapeamento geológico 1:50.000 de parte das follhas Cermo da Ávore. Encruzillada do Sul, Figuciras e Vau dos Prestess. RS. Instituto de Geociências. Universidade Federal do Rio Grande do Sul, Porto Alegre. Trabalho de Graduação do Curso de Geologia.

UFRGS 1995. Mapeamento géológicol:25.000 da Follha Arroio da Bica, RS. Instituto de Geociências, Universidade Fèderal do Rio Grande do Sul, Porto Alegre, Trabalho de Graduação do Curso de Geologia.

Vasquez M.L. 1997. Evoluçāo petrogenética dos granitos da Súte Intrusiva Encruzillhada do Sul-RS. Instituto de Geociências, Universidade Federal do Rio Grande do Sul, Porto Alegre, Dissertaçāo de Mestrado, 195p.

Wildner IV. \& Ramgrab G.E. 1994. O Diorito Capim Branco, In: SBG, Congresso Brasileiro de Geologia, 38, Camboriú, Boletim de Resumos Expandidos, 3:61-62.

Manuscrito A-1164

Recebido em 30 de maio de 2000

Revisão dos autores em 10 de julho de 200

Revisão accita em 18 de julho de 2001 